IRA-International Journal of Education \& Multidisciplinary Studies

ISSN 2455-2526; Vol.04, Issue 01 (2016)

Institute of Research Advances

http://research-advances.org/index.php/IJEMS

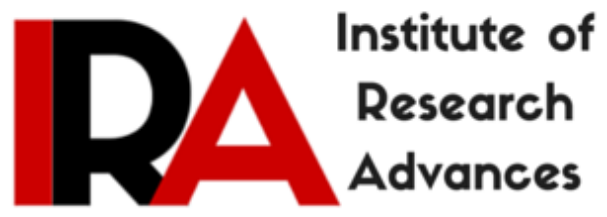

\title{
Swami Vivekananda - As a Poet
}

Dr. Vineeta Tiwari

Computer Centre, R.D. University

Jabalpur M.P. - 482001 India.

DOI: $\underline{\text { http://dx.doi.org/10.21013/jems.v4.n1.p5 }}$

How to cite this paper:

Tiwari, V. (2016). Swami Vivekananda - As a Poet. IRA International Journal of Education and Multidisciplinary Studies (ISSN 2455-2526), 4(1).

doi:http://dx.doi.org/10.21013/jems.v4.n1.p5

(C) Institute of Research Advances

\section{(cc) EY-NC}

This works is licensed under a Creative Commons Attribution-Non Commercial 4.0 International License subject to proper citation to the publication source of the work.

Disclaimer: The scholarly papers as reviewed and published by the Institute of Research Advances (IRA) are the views and opinions of their respective authors and are not the views or opinions of the IRA. The IRA disclaims of any harm or loss caused due to the published content to any party. 


\begin{abstract}
Swami Vivekananda who, in words of Sister Nivedita (Margaret Elizabeth Noble his Irish devoted disciple), breathed India. He was a personality of multiple facets - a thinker, a philosopher, a saint, a preacher, a leader, a reformer and so on. Very few people know him as a Poet. The English poetry in India brought by the ending years of the nineteenth century has chiefly taken the form of a revival of cultural patriotism, highly necessary for a nation. It also has religious impact on it in the sense that it evolved out of the magnificent past of India. And whosoever can be the best admirer of this culture and glory of its past that is one and only Swami Vivekananda. We find a mixture of these aspects in Vivekananda's poetry also but ratio of religion is larger than other aspects of his poetry.
\end{abstract}

Keywords : Personality, Poetry, Nation, Cultural, Patriotism, Religion.

\title{
SWAMI VIVEKANANDA - AS A POET
}

The inclination of the modern mind at present seems to be towards setting predominant value on the thought of poetry. Therefore, we are not only seeing in a poet a supreme singer but a philosopher, a prophet, a teacher, and sometimes a religious preacher. Vivekananda has all these traits in his poetry. In addition to this, patriotism in his poetry didn't leave hope to be free. His soul is full of enthusiasm, seems to come forth for liberty and freedom. He is bold enough and calls out people of his nation to awake and see the new dawn with afresh sun for a new life. He is patriot and prophet in one.

His patriotism was pervaded with concern for the masses to achieve liberation and win democratic rights. That was truly democratic patriotism. ${ }^{1}$

Influence of Vedanta (philosophy) reflects from his poetry. His poems are like mantra of Vedas.

We discover a closer estimation to what we might call the 'mantra' in poetry. The discovery of the word, the divine movement, the form of thought proper to the reality which lies in the apprehension of something stable behind the instability of word and deed. Something that is passion of humanity for something is a dim foreshadowing of the divine urge which is prompting all creation to unfold itself and to rise out of its limitations towards its Godlike possibilities. ${ }^{2}$

Nor I, nor thou, nor God, nor man. The 'I'

Has All become, the All is 'I' and Bliss.

Know thou art That, Sannyasin bold! Say-

'Om Tat Sat, Om!'3

The mantra and poetic expressions of the genuine spiritual reality are only possible when three highest strengths of poetic speech meet up and become indissolubly one, a highest power of rhythmic movement, the highest intensity of verbal form and thought-stuff of style, and the highest force of the soul's vision of truth. Vivekananda's poetry is harmony of these three elements.

Vivekananda's poetry makes higher the pleasure of instrument and transforms it into the deeper delight of the soul: 
I look behind and after

And find that all is right,

In my deepest sorrows

There is a soul of light. ${ }^{4}$

He illustrated in his poetry, the very nature of his thought-power and the distinctive way of expression of the born philosopher:

"From dreams awake, from bonds be free!

Be not afraid. This mystery,

My shadow, cannot frighten me!

Know once for all that I am He! $!^{5}$

We can keep Vivekananda in category of metaphysical poets as metaphysical components can easily be recognized in his work. His poems utter metaphysical characteristics:

Before the sun, the moon, the earth,

Before the stars or comets free,

Before e'en Time has had its birth-

I was, I am, and I will be! ${ }^{6}$

Imagery in Vivekananda's poetry gives an emotional accuracy of the poet's artistic experiences and his imaginative power:

The moon's soft light, the stars so bright,

The glorious orb of day,

He shines in them; His beauty-might-

Reflected lights are they.

The majestic morn, the melting eve,

The boundless billowy sea,

In nature's beauty, songs of birds,

I see through them-it is $\mathrm{He}^{7}$

Many of his poems are conversational in style and do little violation to prose syntax.

His words, writes Roman Rolland, are great music. I cannot touch these sayings of his, spread as they are through the pages of books, without receiving an excitement through my body like an electric shock. And what shock, what transports must have been generated when in burning words they issued from the lips of the hero! $!^{8}$ 
His style of writing is not very different from that of his equals like - Rabindra Nath Tagore and Aurobindo. His poetry is distinguished for consistency and maturity. His poetry has a smooth musical flow. He has written simply and logically. He is a philosophical poet and proceeds steadily in the treatment of his subject.

On the whole, he certainly occupies a distinctive place in realm of modern Indo-Anglican poetry.

\section{REFERENCES -}

1. A.V. Rathna Reddy, The political philosophy of Swami Vivekananda, Sterling publishers Pvt. Ltd., New Delhi, 1984.

2. Sri Aurobindo - The future of Poetry, Sri Aurobindo Ashram, Pondicherry, I Edn., August 1953.

3. Swami Vivekananda - In Search of God and other poems - 'The song of the Sannyasin', Advaita Ashrama, Mayavati, Seventh Impression, Nov. 1997.

4. Swami Vivekananda - In Search of God and other poems - 'Light', Advaita Ashrama, Mayavati, Seventh Impression, Nov. 1997.

5-6.Swami Vivekananda - In Search of God and other poems - 'The song of the Free', Advaita Ashrama, Mayavati, Seventh Impression, Nov. 1997.

7. Swami Vivekananda - In Search of God and other poems - 'In search of God', Advaita Ashrama, Mayavati, Seventh Impression, Nov. 1997.

8. Swami Nikhilananda, Vivekananda-A biography, Advaita Ashrama, Mayavati, Eighth Impression, June 1996. 